\title{
The Medium is the Message. Olivier Schrauwen's Arsène Schrauwen beyond Expectations of Autobiography, Colonial History and the Graphic Novel
}

\author{
Benoît Crucifix, Université de Liège \& Université catholique de Louvain / FNRS
}

Gert Meesters, Université de Lille

\begin{abstract}
This article proposes a close reading of Olivier Schrauwen's Arsène Schrauwen, focusing on the various cultural discourses that it engages with, and particularly its ironical self-positioning within the field of comics. First of all, Schrauwen playfully questions the entrenchment of autobiography in the contemporary graphic novel by presenting a wholly fantasized adventure as biographical family history. This play with generic expectations is continued through Schrauwen's reliance on the tropes of the adventure story and its figuration of the voyage. Arsène Schrauwen also draws on stereotypical images of both Belgium and the Belgian Congo and integrates them into a grotesque narrative so as to question the supposed unicity of the individual and colonial bodies. Last but not least, the book displays a highly self-reflexive approach to comics storytelling, building on a legacy from Flemish comics in order to play with reading conventions, graphic enunciation and abstraction, thereby thematising the perception of the main character.
\end{abstract}

Keywords: Autobiography, Belgium, Congo, Cultural Memory, Flemish Comics, Graphic Novel, Irony, Self-Reflexivity

'Real life is what happens in your head while you're doing the dishes' and '[o]ften I have an idea [what my next story is going to be about], but usually my subconscious has other plans'. ${ }^{1}$ These citations from a recent interview are quite typical of Olivier Schrauwen and make it clear that a story about the Belgian Congo in his hands might result in something very different from the usual well-documented colonial story. In 2014, at Fantagraphics, Olivier Schrauwen published Arsène Schrauwen, in which he imaginatively explores the journey of his grandfather to the Congo. While memoirs of generational testimony are now an entrenched genre in comics production on both sides of the Atlantic, Schrauwen breaks away from this non-fictional approach and delivers an ironically strange, at times even absurd and playfully self-reflexive narrative. Beyond this apparent weirdness, Arsène Schrauwen is an exotic adventure that taps into the Belgian colonial imaginary to reflect on cultural differences, otherness in general, and on the comics medium itself. After a brief introduction to Schrauwen's work, we will show how Arsène Schrauwen emphatically stays away from reality-based graphic novel genres such as autobiography or the travelogue, while still making use of their structural elements and tropes. Schrauwen embraces the history of comics and the two-dimensionality of the medium, not for a selfcontained play with the form, but to use them as enhancements of his multilayered adventure story.

If one considers Arsène Schrauwen to be Olivier Schrauwen's first 'graphic novel' as it is his first professionally published long-form comic, it comes surprisingly 'late' in the career of an author who is already firmly established as a key figure in the field of alternative comics and on the graphic novel scene. ${ }^{2}$ Indeed, since his debut book My Boy, published in 2006, Schrauwen has built an international reputation, as the series of prizes and nominations that he has collected over the years shows. My Boy won him the debut prize at the Turnhout Stripgidsfestival in 2007 and all three books that were translated into French before 2015 got a nomination for the album prizes at the influential International Comics Festival in Angoulême. With the institutional support of the Vlaams Fonds voor de Letteren [Flemish Literature Fund], all his books have been published into English and up to six other languages.

After a childhood in Bruges, Schrauwen attended animation courses at the KASK school in Ghent before turning towards the Master's degree in comics at Sint-Lukas in Brussels (now LUCA School of Arts), which, since the late 1990s, has been instrumental in bringing about a renewal of the comics form in Dutch-

1 'Het échte leven is wat er in je hoofd omgaat tijdens de afwas' and 'Soms heb ik wel een idee, maar meestal heeft mijn onderbewuste andere plannen', cited and translated from Gert Meesters, 'Verover de wereld, verzin je opa' [Conquer the world, invent your grandfather], interview, Knack Focus (February 25, 2015), 18,19

2 See Gert Meesters, 'Les bandes dessinées d'Olivier Schrauwen : de l'art personnel au service d'un internationalisme radical' [The Comics of Olivier Schrauwen: Personal Art for a Radical Internationalism], Septentrion 44.3 (2015), 61-66; Gert Meesters, 'Graphic Novels : A Blessing or a Curse to Comics? About Brecht Evens's Enthusiasm and Olivier Schrauwen's Resistance', forthcoming. 
speaking Belgium. ${ }^{3}$ In his comics work, he has always favoured the short form, a choice that is strongly rooted in his active participation in small-press periodicals and alternative magazines: the narrative design of his books owes much to this earlier stage of pre-publishing. In this way, his first 'graphic novels' My Boy and The Man Who Grew His Beard were both collections of short comics that did not add up into single narratives, privileging rather a sort of fragmented series of self-contained gags about different subjects and, for the second book, drawn in a diversity of graphic styles. Subsequent publications included 30,000 Years of Bad Luck and Le Miroir de Mowgli ['Mowgli's mirror'], both small print-run and short-spanned publications. Greys, an autofiction about an abduction by aliens, was his first longer story, spanning fifty-six two-panel pages, in black and white on grey paper to illustrate an elaborate text in captions. ${ }^{4}$ As a self-reflexive spoof autobiography with a large amount of text to which the images respond, its genre and narration can be considered as foreshadowing Arsène Schrauwen.

As appears from this brief overview, Schrauwen is a cartoonist who manages to occupy a double position in the comics field: he is a successful and critically acclaimed graphic novelist, but nonetheless persists with a small-press and do-it-yourself ethos that many comics artists would otherwise abandon once their work had been integrated into the circuits of literary publishing. ${ }^{5}$ This continued reliance on the alternative small-press scene explains his privileging of the short form and his 'non-novelistic' approach to comics storytelling. His first work of novelistic breadth, Arsène Schrauwen, offers yet another example of this dual positioning. Before being published as a one-shot, hardbound book, its first two parts were self-published, printed on a Risograph and distributed by the author (Fig. 1). ${ }^{6}$ The circulation and the materiality of these two earlier versions is fully in line with the do-it-yourself aesthetic that characterizes the small press scene in comics; ${ }^{7}$ and it further directs the physical qualities of the Fantagraphics graphic novel, which is printed on a similar type of paper, much thinner than usual hardbound graphic novels.

\section{Figure 1 near here.}

\section{Arsène Schrauwen and (Auto)biography}

Schrauwen's ambivalent approach towards the graphic novel is further clear in his ironical treatment of autobiographical material. As mentioned above, Arsène Schrauwen was inspired by one of the author's grandfathers, who just after World War II spent some time in Congo, at that time still a Belgian colony. In the opening sequence of the book (Fig. 2), 'O. Schrauwen' is looking straight at the reader and introduces the protagonist as his grandfather Arsène, even listing the facial resemblances between his forefather and himself, so as to strengthen the genealogical link that unites him to the protagonist of the story. Thus, Arsène Schrauwen opens up on a straightforward declaration of autobiography, an autobiography by proxy, so to speak. ${ }^{8}$ However, the reader quickly realizes that this is a highly ironical and playful declaration that is not to be taken at face value, as the book swiftly turns out to be a spoof biography, just as 'O. Schrauwen' is not the flesh-and-blood

3 On recent transformations of the comics field in Flanders, see Gert Meesters, 'De internationalisering van de Vlaamse strip' [The Internationalization of Flemish comics], Praagse perspectieven 6 (2010), 113-130; Gert Meesters, 'The Reincarnation of Independent Comics Publishing in Flanders in the 21st Century: Bries and Oogachtend as Deceivingly Similar Cases', in La bande dessinée en dissidence. Alternative, indépendance, auto-édition/Comics in Dissent. Alternative, Independence, Self-Publishing, eds. Christophe Dony, Tanguy Habrand and Gert Meesters (Liège: Presses Universitaires de Liège, 2014), 127-140; Charlotte Pylyser, An Archaeology of the Flemish Graphic Novel (PhD thesis, KU Leuven, 2014).

Olivier Schrauwen, 30,000 Years of Bad Luck (Antwerp: Bries, [2011]); Le Miroir de Mowgli (Paris: Ouvroir Humoir, 2011), also published in English, Mowgli's Mirror (Washington, DC: Retrofit, 2015); Greys was self-printed and distributed by the author in 2012, another version was reprinted by the Brooklyn-based comics shop Desert Island.

5 It is important to note not only that institutional funding allows him to do so, but also that his Flemish publisher Bries actively builds bridges between small-press editorial practices and the literary mode of publication of the graphic novel. On the double position of Olivier Schrauwen in the comics field, see Meesters, 'The Reincarnation of Independent Comics' and 'Graphic Novels: A Blessing or a Curse to Comics?'.

6 Tellingly, Schrauwen had originally aimed for a publication in three volumes, a choice his editor waived as commercially unviable; see Benoît Crucifix, 'Olivier Schrauwen', interview, du9, l'autre bande dessinée, January 2015: http://www.du9.org/en/entretien/olivier-schrauwen-2.

7 See Emma Tinker, 'Manuscript in Print: The Materiality of Alternative Comics', Literature Compass 4.4 (2007), 1172-1773.

8 Significantly, Olivier Schrauwen called Arsène an 'alter ego' in an interview in the literary supplement of the newspaper De Standaard: Toon Horsten, 'Met een trappist' [With a trappist beer], Standaard der Letteren (February 27, 2015), 12. 
author of the book. The visual rendition of the story, often illustrating Arsène's view, is so comical and exaggerated at times that the first chapter 'Boat', only eleven pages long, should be sufficient for any reader to seriously doubt whether the narration meets the generic expectation of sincerity. If the reader's credulity is not tested when the local population of Congo is shown performing traditional European dances in matching costumes, then it is when Arsène meets an experienced Congo visitor who tells horrifying stories about the effects of a local parasite entering the human body by swimming up the urine stream.

In retrospect, then, the opening sequence becomes ironical, even for readers who are not familiar with Schrauwen's previous work. The somewhat pompous and unflatteringly plump self-portrait of the author suggests the bourgeois lifestyle of a successful middle-aged author, who presents himself as a 'graphic novelist', thereby delivering an auto-parodic depiction of the authorial figure. The term may not arouse suspicion at first glance, for Arsène Schrauwen fits into most people's conception of what a graphic novel is, but coming from an author who has often made fun of the term, the mocking self-portrait and the job title come together as a selfparody. From the first panels onwards, Olivier Schrauwen plays with the (im)probability of his story. In this way, the book continues the self-mocking autobiographical tone that Schrauwen had already adopted in Greys, in which a very unreliable first person narrator identifying himself as 'Olivier Schrauwen' recounts his abduction by aliens. The book similarly opened on a highly ironical paratextual statement on the relationship between autobiography, medium-specificity and the 'ideology' of the graphic novel: ' 'As a professional graphic-novelist I chose to tell this story in comic-form. I believe that precisely in the gray area, the overlap between what can be said with words and what's best shown with images lies the language that can truly convey the profound mystery of the events I've experienced' (Fig. 3). Along similar lines, Schrauwen's latest publication, 29,000 Years of Bad Luck, is a minicomic ironically carrying the label 'graphic novel', once again defying generic expectations.

\section{Figure 2 and}

Figure 3 near here.

In fact, Arsène Schrauwen was not even Olivier's grandfather's name. His grandfather Arsène's surname was Puype, the maiden name of his mother. ${ }^{10}$ The real Arsène did go to the Congo as a young man, but Schrauwen had never heard him speak about the experience and had only ever seen one photograph. ${ }^{11}$ The rest of the story is the result of Schrauwen's imagination at work with the larger Belgian colonial memory. It quickly becomes clear that Arsène Schrauwen stands miles away from the careful archival and documentary work of graphic novelists seeking to recover their family history, a genealogical trope that is moreover particularly found in (post)colonial comics narratives trying to grapple with the heritage of colonialism. ${ }^{12}$ Therefore, one can safely claim that the author makes fun of factual/non-fictional(?) genres as the travelogue, the documentary, the biography and autobiography by pretending to succumb to the fashion for reality-based comics. In this sense, Arsène Schrauwen parodies and challenges the frequent conception of the medium in comics studies as a 'predominantly ethical medium, comprised of personal relations between artist and reader', ${ }^{13}$ but it also selfconsciously references comics history and conventions, following Jan Baetens and Hugo Frey's nuanced description of the graphic novel as a 'self-knowing "play with a purpose" of the traditional comic book form'. ${ }^{14}$ Schrauwen establishes links with comics that do not belong to the graphic novel paradigm and pushes this 'play' one step further through his parody of the now-traditional graphic novel. His irony reminds the reader of the total potential of the comics medium. He argues in favour of fictional stories, nourished by formulaic pulp tales as

$9 \quad$ For a nuanced analysis of the privileged position of autobiography in the graphic novel, see Baetens and Frey, The Graphic Novel, 176-180. On the ideological stakes of autobiography in European comics since the 1990s, see Bart Beaty's chapter 'Autobiography as Authenticity', in Unpopular Culture: Transforming the European Comic Book in the 1990s (Toronto: University of Toronto Press, 2007), 138-170.

10 Gert Meesters, 'Verover de wereld, verzin je opa', 19.

11 Toon Horsten, 'Met een trappist', 12

12 The worldwide success of Spiegelman's Maus has of course been capital in establishing this trend in comics; following that example, many graphic memoirs draw on forms of generational testimony or seek to reconstruct complex family histories. On this topic, see Benoît Mitaine, 'Au nom du père, ou les “autobiographies” de ceux qui ne dessinent pas (Altarriba, Gallardo, Spiegelman, Tardi)' [In the name of the father, or the 'autobiographies' of those who do not draw (Altarriba, Gallardo, Spiegelman, Tardi)], in Autobiographismes : Bande dessinée et représentation de soi [Autobiographisms: Comics and SelfRepresentation], eds. Viviane Allary, Danielle Corrado and Benoît Mitaine (Geneva: Georg, 2015), 171 194. On genealogical postcolonial narratives in comics, see Mark McKinney, Redrawing French Empire in Comics (Columbus: The Ohio State University Press, 2013), 12-13.

13 Daniel Worden, 'The Politics of Comics: Popular Modernism, Abstraction, and Experimentation', Literature Compass 12.2 (2015), 69.

14 Baetens and Frey, The Graphic Novel, 19. 
equivalent to more reality-based work. In so doing, he establishes a paradox: Arsène Schrauwen raises questions about 'writing the self' because the author and his family seem to take centre-stage, although it bears no resemblance to real events at all. Schrauwen claims to talk about himself and his family only to keep away from strictly (auto)biographical elements. Of course, as with most writing, personal themes emerge. Veracity is not a necessary condition to tell a personal story, as Schrauwen clearly realizes.

\section{Beyond Genres}

The pulp subtext that Schrauwen draws on to construct the spoof biographical adventures of his grandfather is announced by the cover (Fig. 4), which cheerfully outlines the main themes of the book. It reads: 'a comic about: Arsène, venture, love, architecture, freedom, fear, lust, the unknown, nothing, projection, expectation, new acquaintances, bullshit-artistry, entrapment' with each keyword being associated with a specific image, already alluding to the narrative inside. Although Schrauwen twists it in his own way, the cover alludes to the paratext of pulp fiction and comic books, which often relied on self-explanatory titles and additional text to announce popular themes and generic features. The analogy is even stronger in the original, risoprinted versions, as their materiality evokes the ephemeral, trashy quality of cheap print entertainment: it is printed on pulp, its size comes closer to the dimensions of comic-book 'floppies', and the cover does not feature the author's name. In this way, the cover of Arsène Schrauwen references reading practices tied to popular genres, in which the reader seeks serial, intertextual and generic repetitions of themes rather than the reference to the real. ${ }^{15}$ What the cover of Arsène Schrauwen suggests, is precisely that the book is not so much 'about' factual biographical material that references a real or authentic experience, but rather that it invokes typical tropes from popular genres as the adventure story. This appropriation of classic motifs, however, happens in an offbeat, ironical fashion as Schrauwen persistently seeks to undercut generic expectations. ${ }^{16}$

\section{Figure 4 near here.}

Thematically, Arsène Schrauwen displays many characteristics of the 'voyage initiatique' [initiatory journey], a journey that develops one's character, often involving romantic entanglement and the exploration of unknown territory. Arsène is a young adult, in his mid-twenties, when he travels to the Congo. In all his naiveté, he is like a kid, as can be deduced from his cousin Roger's assertion at the end of the book that his toddler son looks just like Arsène when the latter arrived in the Congo ${ }^{17}$ In the colony, Arsène is received as a man full of promise by Roger, who employs him in his megalomaniac city building project. Arsène seems to have high hopes for himself. When asked what he is looking for in the Congo, he replies 'freedom', ${ }^{18}$ thus inspiring his cousin with the idea of the name 'Freedom Town' for the new city to be built. Initially a nobody without a clear purpose, he seems to rise to the occasion. When his cousin Roger is hospitalized, Arsène is given the responsibility for the whole expedition into the jungle, necessary to start building Freedom Town. Also, during his cousin's illness, he starts an intimate relationship with Marieke, Roger's wife. As this is his first sexual relationship, it boosts his self-confidence. ${ }^{19}$ Whether this effect on Arsène's self-image is justified, as the relationship is only shortlived, is arguably questioned at the moment of their sexual union, as a person outside who hears groaning, utters the words 'poor bastard', which probably refer to an ill person inside, but could also be read as a narrator's commentary on Arsène's fate. ${ }^{20}$

In portraying Arsène's romantic adventure with Marieke, Schrauwen uses an interesting metaphor. Shortly after meeting Marieke and falling in love at first sight, the protagonist finds a big key in the bungalow where he resides. In spite of trying all the locks in the building, Arsène does not find a use for it. Eventually, he discovers that this is the key to his letterbox. ${ }^{21}$ Since it took him weeks to find it, it is filled with letters sent by Marieke, who seems as fond of him as he is of her. The key had already become a phallic symbol, as the author suggested by image rhyme ${ }^{22}$ and Marieke becomes the lock that fits Arsène's key, as shown in the beginning of

$15 \quad$ See Matthieu Letourneux, 'La notion d'aventures dans les productions populaires : roman, cinéma et jeu d'aventures' [The Concept of Adventure in Popular Productions: Novel, Cinema and Adventure Games], Belphégor 3.1 (2003): http://etc.dal.ca/belphegor/vol3_no1/articles/03_01_Letour_aventu_fr_cont.html.

16 Of course, this also constitutes a rather typical positioning for 'graphic nove-elists' who often take a firm stance 'against' what is perceived as the genre formulas of traditional comics. Schrauwen, however, never loses sight of the fact that working in the graphic novel paradigm is just as much bound to genre as mainstream production.

17 Olivier Schrauwen, Arsène Schrauwen, 253.

18 Arsène Schrauwen, 39.

19 Arsène Schrauwen, 186.

20 Arsène Schrauwen, 181.

21 Arsène Schrauwen, 108.

22 Arsène Schrauwen, 60. 
their second meeting, when he runs towards Marieke and imagines her contours to be the lock that he can put the key into. ${ }^{23}$ Later on, just before they first have sexual intercourse, Arsène is looking at Marieke through a keyhole. ${ }^{24}$ As corny and obvious as this metaphor may be - it is even explained on the back cover, where lock and key illustrate the word 'lust' - it serves to parody the classic love story that is often part and parcel of an adventure story, of which the initiatory journey can be considered a subgenre. It ironically reacts to the reader's expectation of a blossoming romantic entanglement that traditionally goes together with discovering unknown territory abroad. Although the storytelling in Arsène Schrauwen is quite literary in the sense that the text contains almost all the necessary information to follow the story - Schrauwen first wrote the story as prose before drawing a comics version ${ }^{25}$ - this metaphor is only one of the numerous ways in which Schrauwen shows just as much special attention to visual narration.

Despite the traditional schema of leadership and romance in an adventure story, Arsène as a protagonist does not resemble the typical action hero. He is too passive to take his destiny into his own hands. His leadership is the result of a coincidence, i.e. cousin Roger's illness, and he rarely shows the abilities to be a good leader. Either he startles his men by a sudden outburst of unexpected authority or he leaves the real leadership to others when he can: Marieke whispers the right things to say in his ear, ${ }^{26}$ he lets Marieke drive the car while he sits in the passenger seat, ${ }^{27}$ Louis and Marieke correct the mistakes that he makes when he has to guide the convoy into the jungle and gets lost. When his anger flares after tension has been building up for weeks in his lonely bungalow, he cannot even bring himself to kill a baby ostrich, although he sees it as a perfect victim to channel his frustration..$^{28}$ This ostrich will follow him around afterwards, as a visual reminder of the cowardice the bird is often associated with.

In spite of the rare moments of action, Arsène remains so passive that he hardly learns anything from what he goes through. His short responsibility as a leader has not taught him anything. He has just escaped being sodomized by leopard men, but he does not even dare to write down the experience for fear that nobody will believe him or that he will go insane. ${ }^{29}$ At the end of the book, his affair with Marieke almost seems unreal. ${ }^{30}$ In short, as the narrator says, looking back on the fearful episode after having finally decided to leave the bungalow where he has been living for weeks: 'It was a strange and cathartic event. One that might have provided him with insight into his own psyche. Grandpa saw it differently though... It was an embarrassing little episode that should be forgotten as soon as possible'. ${ }^{31}$ By profiling a character who prefers not to learn, Olivier Schrauwen makes the whole 'voyage initiatique' scheme fall apart, while again making fun of a well-established story genre.

\section{Figure 5 near here}

Arsène's preference to preserve his ignorant state is corroborated by the structure of the book. A double page, almost in the middle of the story, draws the reader's attention to this aspect (Fig. 5). Here, Arsène is shown in his own bungalow. The background is represented only once, but Arsène is depicted over and over again, much like Killoffer in 676 apparitions de Killoffer [676 Apparitions of Killoffer]. ${ }^{32}$ Successive moments in time are represented as if they were simultaneous, multiplying apparitions of the character within one panel $-\mathrm{a}$ technique Paul Gravett has called the 'De Luca effect'. ${ }^{33}$ The text mentions that time seemed to have become circular and even the captions carrying that text are arranged in a circle. In the image, in addition to the multiple images of Arsène, the mirror effect stands out. Although variations remain in the representation, four Arsènes fastening their underpants stand back to back in a square. Three Arsènes on a chamber pot are neatly arranged: one facing left, one in the middle and one facing right. This scene shows a moment in the story when Arsène is caught in his own fear and as a result, he is immobilized, but its significance reaches further than this moment in the story: the structure of the whole book is circular. Many story elements from the beginning return at the end: the physiognomic resemblances between Olivier and Arsène, ${ }^{34}$ the simplified image of a boat, ${ }^{35}$ Arsène's bike

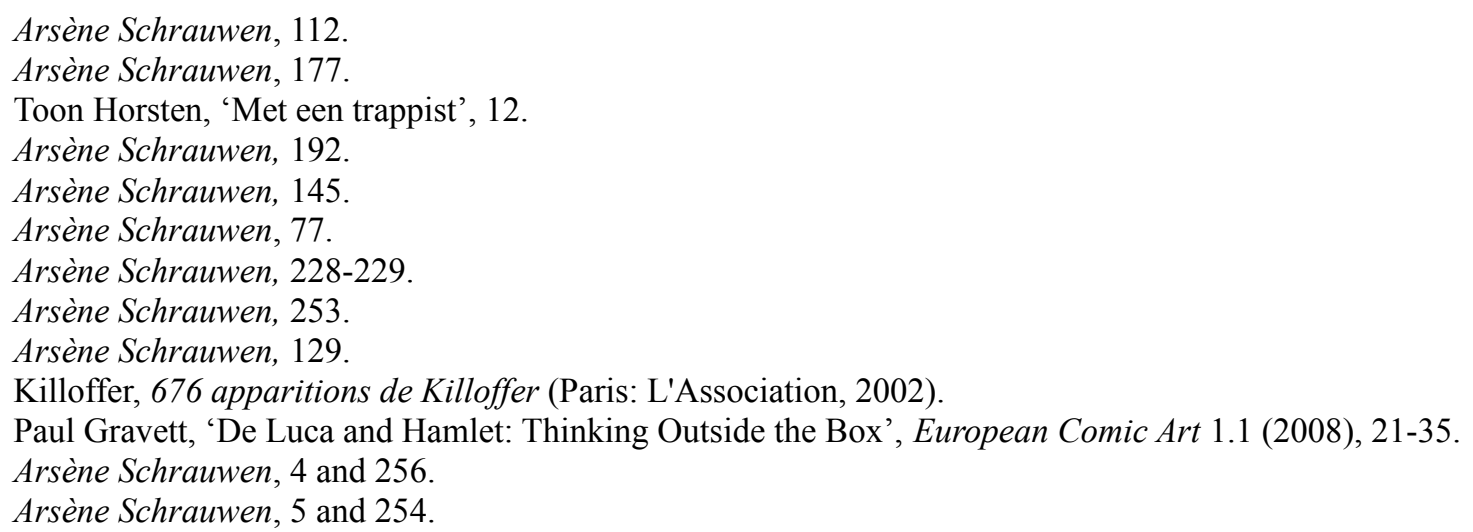


that is still where he had left it two years previously. ${ }^{36}$ Another beautiful repetition that arguably shows that the circular structure is not just a meaningless way of delimiting the time period in which the voyage took place, is the piano on Arsène's back. When first confronted with the moist heat in the tropics, he feels as if a piano had been thrown on top of him. Near the end of the book the piano in the image returns on Arsène's back in order to show how heavy is the climb to his home after he has witnessed the reconciliation between his cousin Roger and Marieke (Fig. 6).

\section{Figure 6 near here}

\section{The Belgian Congo, the Hybrid and the Grotesque}

As should be clear by now, Schrauwen's representation of his grandfather's journey to the Congo is not attempting to reconstitute the 'real' story. In accordance, he does not lay claim to a realistic representation of the Belgian colony, and the country that Arsène travels to is itself clearly an imaginary construct. Nonetheless, Schrauwen also strongly relies on key tropes in the cultural memory of the Belgian Congo, tapping into that reservoir of images and stories and integrating these elements into his fictional story.

At first, Schrauwen undoubtedly invokes the typical trope of the Congo as a 'locus of degeneration', most famously instantiated by Joseph Conrad's Heart of Darkness. As Sarah De Mul has argued, ${ }^{37}$ this trope was ubiquitous in the context of late-nineteenth-century Europe, and, given the strong resonance of Conrad's book, found widespread echoes and reminiscences throughout the twentieth century, leaving a remarkable imprint on the memory of the Belgian colonial past. This Conradian paradigm depicts the Belgian colony as the degeneration of European civilization and undermines the then-prevalent rhetoric of progress, but it also paradoxically constructs an othering discourse of Africa complicit in confirming Western civilization. Indeed, Heart of Darkness relies heavily on a depiction of Congolese nature as wild, gloomy, destructive - an alien force actively resisting the imposition of Western constructs, which are themselves not particularly challenged.

This is a trope that has continuously nourished more recent descriptions of the Congo, as in the literary works of V. S. Naipaul or Lieve Joris, and it has recently boomed in contemporary comics production. In the last decade, as documented by Véronique Bragard, there has been a wealth of comics dealing with the Congo, most of which strongly rely on this Conradian paradigm. ${ }^{38}$ While these works often foreground or at least attempt to suggest a certain degree of historical truthfulness, ${ }^{39}$ Olivier Schrauwen's openly non-factual and imaginative representation of the Congo taps into this Conradian vision of the Belgian colony as the 'Heart of Darkness' but in a hyperbolical grotesque manner that clearly differentiates it from this trend visible elsewhere. Schrauwen reuses this trope not in order to appropriate its cultural authority (indeed, there is no direct or explicit reference to Conrad's text), nor to express a narrative of guilt with regards to Leopold's colonial regime. Instead, he tilts it upside down in a more off-kilter fashion, raising different questions and eventually reworking the Congo as 'locus of degeneration' into a more generative 'locus of hybridization'.

While the wild jungle and madness pervade Arsène Schrauwen, the episode that most conspicuously epitomizes Schrauwen's grotesque treatment of the Conradian paradigm is the fourth chapter, 'Water,' in which the protagonist, after having spent days alone in his hut, gives way to complete madness during a heavy rainfall. Obsessed by the fear of elephant worms, which, Arsène was told, are parasites swarming everywhere in the water and which can swim up your urine stream and transform you into an amorphous mass of flesh, ${ }^{40}$ he persistently attempts to shut his body off to this exotic threat: keeping away from all water, taping up his pants, etc. Trying to hold his body as a closed-off, hermetic unit, he shuts himself off from the alien environment in which he has landed. The rainfall, with its potential downpour of elephant worms, pushes his endeavours to a point where he cannot hold it off anymore. Locked up in his cabin, he gets trapped into a circular, cyclical

$36 \quad$ Arsène Schrauwen, 6 and 255.

37 Sarah De Mul, 'The Congo as Topos of Dystopic Transgression in fin-de-siècle Literature', Tydscrif vir letterkunde [Journal of literature] 46.1 (2009), 95-108.

38 Véronique Bragard, 'Guilty Melancholia and Memorial Work: Representing the Congolese Past in Comics', in Postcolonial Comics: Texts, Events, Identities, eds. Binita Mehta and Pia Mukherji (London: Routledge, 2015), 92-110. For a historical perspective on representations of the Congo in Belgian comics, see Pascal Lefèvre, 'The Congo Drawn in Belgium', History and Politics in French-Language Comics and Graphic Novels, ed. Mark McKinney (Jackson: University Press of Mississippi, 2008), 166-187.

39 Interestingly, these works tend specifically to recuperate Heart of Darkness as a political pamphlet, with its author, Conrad becoming something of a heroic figure, as in Kongo : Le ténébreux voyage de Józef Teodor Konrad Korzeniowski [Kongo: the dark journey of Józef Teodor Konrad Korzeniowski] by Christian Perrissin and Tom Tirabosco (Paris: Futuropolis, 2013).

40 Arsène Schrauwen, 12. 
routine - a motif 'braided' throughout the book and symbolic of madness ${ }^{41}$ - indicating that there is no way out. As the water starts flooding into Arsène's hut, the rain motif in the background increasingly encroaches upon the space taken up by the panels, showing how the character is increasingly confined to a smaller space (Fig. 7), 'reduced to the smallest possible instance of himself', ${ }^{42}$ until he explodes into a 'primordial cry,' opening himself up to the rain, gulping the water, embracing his environment. It is a metaphoric rebirth, the 'moist, hot' 43 bungalow obviously standing for a womb.

\section{Figure 7 near here}

In a typically grotesque manner, Schrauwen highlights the borders between the body and its surroundings. Mikhail Bakhtin, in Rabelais and His World, has argued influentially that the grotesque relies on a 'special concept of the body as a whole and of the limits of this whole'. ${ }^{44}$ The grotesque constantly revolves around acts and motifs that are positioned at the interstices between the limit of the body and its exteriority; as Bakthin writes:

The grotesque body [...] is a body in the act of becoming. It is never finished, never completed; it is continually built, created, and builds and creates another body. Moreover, the body swallows the world and is itself swallowed by the word [...] Eating, drinking, defecation and other elimination (sweating, blowing of the nose, sneezing), as well as copulation, pregnancy, dismemberment, swallowing up by another body-all these acts are performed on the confines of the body and the outer world, or on the confines of the old and new body. In all these events the beginning and end of life are closely linked and interwoven. ${ }^{45}$

The grotesque body and the reconfiguration of boundaries between humanity and animality are in fact key themes in Schrauwen's oeuvre: they feature prominently in Le miroir de Mowgli, his rewriting of Kipling's Jungle Book, and were already perceptible in My Boy, where a visit to the Zoo - the very place where such boundaries are traditionally defined - turns into a chaotic rebellion that disrupts these borders and their connections to race. Arsène Schrauwen features a similar play with categories of humanity and animality. In its fascination for the grotesque body, the relationship to animals, or the representation of the human as an animal, occupies an important place. Animals repeatedly function as visual metaphors for the protagonist's relationship to his new surroundings: Arsène, for instance, is often represented as a bird or as a chicken and mostly as a donkey, which comes to stand quite unequivocally for lust. Indeed, Schrauwen uses the sequence, by a typical play with repetition and difference, to introduce a comic representation of Arsène as a donkey, whenever the protagonist gets an erection. ${ }^{46}$ Besides embodying quintessentially grotesque physical activities, these playful representations of Arsène as animals further construct a grotesque vision of a 'body in the act of becoming': they visually crystallize moments of physical transformation.

The grotesque further appears in the fact that Arsène does not crave much more than the fulfilment of his basic, physical needs: eating, drinking, sex, smoking. But these basic activities turn out to be reconfigured by his voyage to the colony: alone in his bungalow, uneasy with the ostrich eggs that stack up in his kitchen, the only thing he manages to ingest is the large supply of trappist beer. Spurred by the fear of elephant worms, Arsène's attempt to seal his body off, to keep his bodily limits hermetic to the new environment parodies the colonialist communities depicted in the book, trying to preserve cultural habits they import and impose onto the colony: drinking trappist beer, eating tomates crevettes and éclairs, constructing buildings that recreate a comforting Belgian environment, such as the small coastal town in which Arsène arrives that 'doesn't look much different than any small Flemish town on a hot summer day', ${ }^{47}$ or that other palace replicating the feeling of 'some fancy historical site in Europe'. ${ }^{48}$

In Arsène Schrauwen, Belgian culture is certainly not portrayed as the zenith of civilization. It is reduced to a caricature of some typical dishes, trappist and table beer, uninspired architecture and sanseveria houseplants. Interestingly, Schrauwen completely leaves out the possibly normative role of Roman Catholicism, a strong force in Belgian society at the time, but does thematise the uneasiness about black people that was ubiquitous, Belgium being a very homogeneous society until the 1960s. This uneasiness is most visible in the

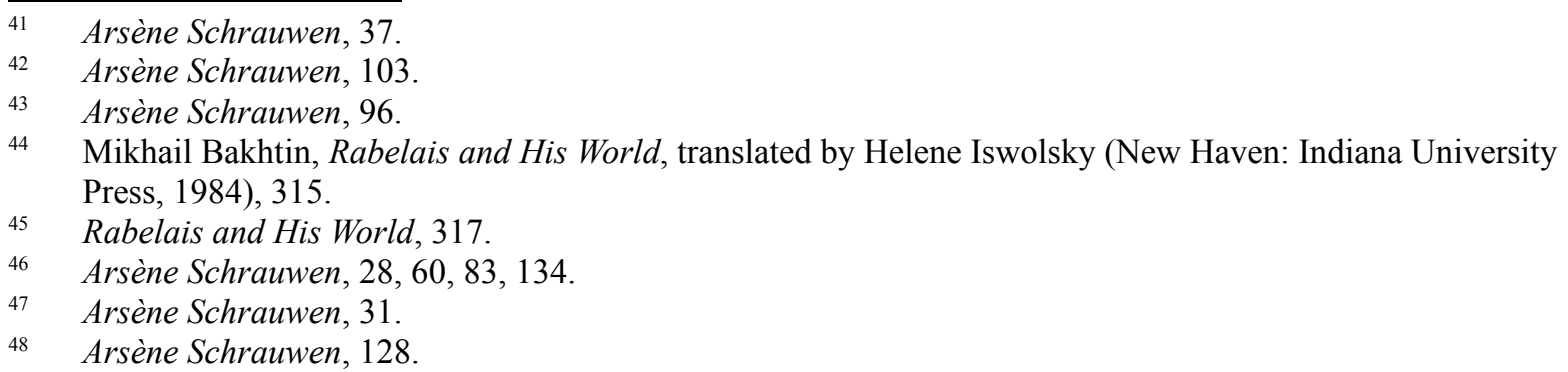


relationship of Arsène with his servant, the 'boy'. He tries to meet him, even goes to his house, but the latter remains nowhere to be found. All communication between them happens in writing. The narrator clarifies their relationship in a toy that shows two people moving clockwise at the same speed, without being able to reach the other. ${ }^{49}$ Only very late in the story do realistic black people make an appearance. ${ }^{50}$

As Arsène moves further into the country, deeper into the interior, limits and borders are increasingly blurred and mixed into a Conradian, destructive wilderness actively resisting the colonial enterprise. On their way, the caravan stops at an old, ruined Belgian theme park, which 'had been conceived for Belgian colonist families ${ }^{51}$ with the purpose of recreating an ersatz of life back in the home country: a vegetable garden with cabbage, a zebra posing as a donkey, miniature versions of Belgian monuments, a bar, etc. (Fig. 8). This semblance of Europe, also evident in the examples mentioned previously, did not last long, as the Congolese jungle has reclaimed the space. The same jungle transforms disposed-of herring into new hybrid and monstrous creatures, ${ }^{52}$ it is also the site where a scout is transformed into a bulging, monstrous body after a supposed contact with elephant worms, ${ }^{53}$ and where the whole convoy is assaulted and raped by leopard men. ${ }^{54}$ If experienced as a wild, alien, and dangerous natural force opposing the colonial enterprise, the jungle is not so much a locus of degeneration as in Conrad's novella, but rather a locus of hybridization. While in the Conradian paradigm, the wilderness is the site where Western civilization does not 'take' and instead degenerates, in Arsène Schrauwen, things do not die off, but are transformed into new hybrid creatures: the jungle is the place that reshapes heterogeneous elements into a kind of cultural métissage. The leopard men are indeed a new kind of creature, engendered from the sexual union between a somewhat crazy Belgian monk and a leopard; the cabbages transform into gigantic hybrid species, and so on. This hybridization continues the grotesque vision of the body, extending it to the social body of cultural communities, and confronting Arsène with his own identity. Arsène's fear, as very much epitomized in the two chapters discussed here, is to be transformed by this other country, by alterity; ultimately, it turns out be a fear of hybridity.

\section{Figure 8 near here}

The tendency towards hybridity can also be unearthed in the characteristics of the architecture depicted. Cousin Desmet's home is an extravagant geometric building that shows man's ambition to express himself through architecture, echoing the famously grandilose projects of Leopold II, and also, later on, those undertaken in the Congo by Mobutu. ${ }^{55}$ In contrast to these two examples, however, Desmet is a visionary who allows coincidence to determine the nature of his endeavours, as can be seen in the Bricolage Monument, a collage of objects that a lot of people would call ridiculous. The narrator repeatedly refers to Desmet's designs as 'funny'. ${ }^{56}$ Desmet also shows a childlike enthusiasm about his own building projects that is apparent when he presents the geometric and impractical costumes that he has designed, an event leading to the literal and figurative burning up of his home. His enthusiasm is even clearer while working on the scale model of Freedom Town (Fig. 9). His attitude is not unlike a young child's revelling in playing with unusual building blocks. Moreover, the presence of a ball pool in the scale model reinforces the playful aspect of Desmet's vision of architecture.

\section{Figure 9 near here}

The scale model of the city also reveals the dynamic aspects of architecture in the book. The omniscient narrator stresses the natural feel of the model: 'The way the infrastructure was composed, the tissue of interwoven streets and canals that connected parks and plazas seemed organic. The whole thing laid in a cardboard valley like a man resting in a pile of hay' ${ }^{57}$ Consistent with this citation, the scale model seems to have grown organically later on. ${ }^{58}$ Nevertheless, Desmet's naiveté, open mind and creative urges either lead to or cannot keep him safe from madness. His troubled state of mind after setting fire to his home completes Desmet's embodiment of the trope of the mad inventor, ${ }^{59}$ an omnipresent character in mid-twentieth Century Belgian comics. Just like other inventors in comics, he excels in designing transportation, e.g. the motor vehicle with

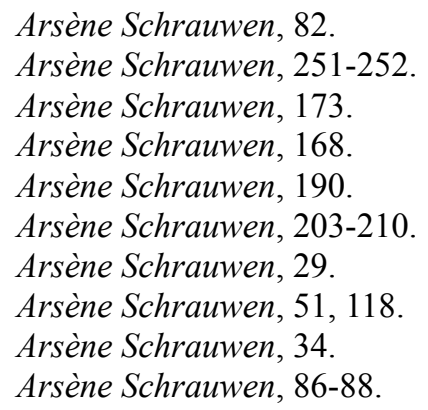

His talents are referred to as 'maniacal ingenuity'; Arsène Schrauwen, 160. 
compartments to carry both building materials and mobile bedrooms. ${ }^{60}$ Desmet's delirium and madness can be attributed to his stay in the Congo, as the unfamiliar surroundings often lead to this effect in colonial literature. Just like Arsène, who implodes emotionally in the isolation of his bungalow, strangely trying to keep away from life-giving water, Desmet is not capable of staying sane in a disorienting country. Keeping a Belgian lifestyle with trappist beer and tomate crevette or attacking a stranger when expecting a visitor attest to Desmet's lingering uneasiness with the colony. ${ }^{61}$

The organic aspect of architecture in Arsène Schrauwen also shows in the deserted Belgian amusement park in the jungle, which has become a mix of nature and culture. It can be fruitfully linked with Desmet's scale model, as his assistant Louis already remarks about the project: 'If you keep on adding models, it will start looking like a funfair' ${ }^{62}$ In the actual amusement park at which Arsène and the rest of the convoy stop, plants have re-conquered the space and have become an integral part of it. ${ }^{63}$ Its state reminds one of lost Inca sites, of Angkor or other traces of civilization that have become one with nature. In Arsène, the traditional opposition between nature and culture thus does not make much sense.

The dynamics of architecture can finally be seen in a more traditional way. Desmet's vision being extravagant and modernistic, the developing Freedom Town reverts to a more traditional city ${ }^{64}$ when the reality of the local economy, with developing mines and industry, takes over. Desmet's architectural vision, using the colony as an opportunity to start anew, was maybe too idealistic to be executed in full. Therefore the takeover by more traditional architecture can be considered a return to normal. This is hinted at by the synthesis of the colours blue, red and black in the couple of pages in which Arsène leads a regular life in Congo, buying the skins of the leopards (leopard men?) of which he was once afraid. ${ }^{65}$ This equilibrium is short-lived, however, for the end of the story recalls the beginning and is again executed in monochrome blue.

\section{The Legacy of Flemish Comics}

Schrauwen's most recent comics explicitly show his position in ongoing debates in the medium. As previously argued, Arsène Schrauwen parodies the reality-based genres that are associated with the graphic novel and which have won the medium more general prestige and scholarly attention in recent years. Obviously, Arsène Schrauwen also relies on a narrative span that readers might associate with a graphic novel, draws on literary tropes of the Congo, and finally, the passive carelessness of Arsène displays traits of a boredom typical of some graphic novels. ${ }^{66}$ Working within that paradigm, Schrauwen nevertheless brings in references to popular comics and displays a rootedness in classic comics culture. ${ }^{67}$

For one thing, Schrauwen's decision to publish the story in three instalments can be likened to the practice of serialization that has been fundamental to comics and links Arsène more specifically with the series the author grew up with. Furthermore, the leopard men have held a particularly strong position in the colonial imagery of comics: most cartoonists documented their drawn adventures in the Congo by paying a visit to the Africa museum in Tervuren, close to Brussels, where Paul Wissaert's famous sculpture of leopard men can be found. As such, they appear in Hergé's Tintin au Congo, of course, and also turn up later on in Desorgher and Desberg's nostalgic series Jimmy Tousseul. As a token of their association with traditional Franco-Belgian bande dessinée, Yann and Schwartz have also introduced leopard (wo)men in their latest Spirou par album, riddled with clins d'œeil and allusions to comics culture. ${ }^{68}$ Traditionally, leopard men, or anioto, dressed themselves in leopard skins to commit revenge crimes mimicking leopard attacks, and most comics participated in their mythification, representing them as disguised black people. Arsène Schrauwen clearly alludes to this well-known trope in Franco-Belgian bandes dessinées, but uses it in a completely different way. Indeed, the leopard men materialize as actual hybrid beings and are given a rather unusual 'origin story' as the 'species' is said to have come from the sexual union of a crazed monk and a leopard.

While this reference to a key trope in francophone comics would still be easy to pick up for an

\footnotetext{
60 Arsène Schrauwen, 159.

61 Arsène Schrauwen, 20.

62 Arsène Schrauwen, 38.

63 Arsène Schrauwen, 172-174.

64 Its new name, Lippensville, is a reference to the character Lippens, who not only has large lips, but also refers to an industrial Belgian family by the same name with colonial interests in Congo.

65 Arsène Schrauwen, 252.

66 The episode in which Arsène remains secluded in his hut seems quite exemplary in this regard. On boredom and the graphic novel, see Greice Schneider, 'Comics and Everyday Life: from Ennui to Contemplation', European Comic Art 3.1 (2010): 37-63.

67 This contrasts with, for instance, the work of other Flemish cartoonists Brecht Evens and Judith Vanistendael who do not present themselves as working in the continuity of a comics tradition, and rather acknowledge the influence of literature and fine art.

68 Yann and Olivier Schwartz, La femme léopard [The leopard woman] (Marcinelle: Dupuis, 2014).
} 
international audience, the same does not apply to other links in the book. Contrasting with the painterly, illustrative styles used in Schrauwen's earlier books, the simple line drawings refer to early Flemish newpaper comic strips, most particularly Suske en Wiske [Spike and Suzy or Willy and Wanda or Bob and Bobette] by Willy Vandersteen and De avonturen van Nero [The Adventures of Nero] by Marc Sleen. ${ }^{69}$ From the forties to the sixties, these were the two most popular comics in Flanders. They both influenced Arsène Schrauwen in a different way.

The use of blue and red in Arsène Schrauwen can be traced back to the colours of early Suske en Wiske albums (except for the stories from Tintin magazine), which were printed in brownish red and greyish blue until the late 1960s. The colour was used as monochrome: ${ }^{70}$ every page was printed in one colour only and every odd number of pages, with the transition from one quire to the next, the colour would change. This monochromatic use of red and blue would quickly become a tradition for the Suske en Wiske albums. ${ }^{71}$ In Arsène Schrauwen, the use of red and blue is primarily tied to the technical constraint adopted in the original risoprinted version: as most Risographs have a single ink drum, they require printing one colour at a time, which restricts the colour palette. Without this distinguishable use of colour in Suske en Wiske, Schrauwen nonetheless says he would never have had the idea to use blue and red as the sole colours for his book. ${ }^{72}$

In the beginning, Arsène Schrauwen seems to follow Suske en Wiske's example closely, by having one colour per page. Soon however, Schrauwen starts using colour in a completely different way, using the shift of colour as a marker in the narrative. This shows how complex colour is in comics and further highlights how 'the dichotomy of black and white versus color is dramatically more complex than what is often thought' ${ }^{73}$ Indeed, colour in Suske en Wiske was used as a chromatic equivalent to the black-and-white monochrome of the original newspaper strips: therefore, the difference between the two colours does not bear any particular relationship to the narrative and can be considered a kind of 'non-colour'. By contrast, Arsène Schrauwen draws on the same two monochromatic colours but Schrauwen does narrativise the difference, using colour as colour in order to highlight subtle shifts or differences in the story. In this sense, colour in Arsène Schrauwen works 'as a process between successive or competing types of color as a contact-zone between monochromatic and polychromatic or vice versa $::^{74}$ there is a permanent tension between the marked narrative function of the colour and its unmarked monochromatic use.

In this process, moments of transition from one colour to the other conspicuously draw the attention of the reader to its function. As such, these colour changes become a vital part of the graphic storytelling. The most evident uses of a meaningful colour shift include the transition from dark nighttime (blue) to bright daytime (red) or a change in temperature, from cold (blue) to hot (red). These uses are evidently linked, since we experience warmth together with the light of the sun. Therefore, red as a colour for light and warmth is a logical outcome of the 'metaphors we live by', as Lakoff and Johnson would put it. ${ }^{75}$ One fine example of colour use to indicate light and dark is the scene where Arsène goes for a drink in an improvised bar in the deserted amusement park in the jungle. Due to a glitch in the functioning of the generator, the neon lights only shine intermittently. Schrauwen shows this by alternating red and blue panels (Fig. 10).

\section{Figure 10 near here}

69 Greys can be seen as a predecessor of Arsène Schrauwen in this respect, as it also thematises its own anachronistic use of greytone, bound to the newspaper comics production.

70 In all 35 albums until 1959. Afterwards, red and blue were still the only colours, but they were mixed on the page (duotone), cf. Rolf De Ryck, Willy Vandersteen. Van Kitty Inno tot De Geuzen, Bibliografie [Willy Vandersteen. From Kitty Inno to De Geuzen, Bibliography] (Antwerp: Standaard, 1994), 89, 104 and Peter Van Hooydonck, Willy Vandersteen. De Bruegel van het beeldverhaal. Biografie [Willy Vandersteen. The Bruegel of comics. Biography] (Antwerp: Standaard, 1994), 73.

71 This colour effect was almost exclusive. Only one other series, Piet Pienter en Bert Bibber by Pom [Jozef Van Hove] was published in red and blue monochromes. In Suske en Wiske, the tradition was so strong that the same colour scheme was used for the entire facsimile edition of the newspaper versions, Suske en Wiske Klassiek, even for the stories that never got this treatment in an album version (the stories published between 1959 and 1967).

72 Meesters, 'Verover de wereld, verzin je opa', 21. Interestingly, in one of his early comics serialized in the comics magazine Ink., in which Schrauwen exercises a multitude of various graphic styles, the author had already drawn a pastiche of Vandersteen's comics, borrowing the same colours: Olivier Schrauwen, 'Macho Man', Ink. 7 (2002), 8-9.

73 Jan Baetens, 'From Black \& White to Color and Back: What Does It Mean (not) to Use Color?', College Literature 38.3 (2011), 114.

74 Baetens, 'From Black \& White to Color and Back', 118.

75 George Lakoff and Mark Johnson, Metaphors We Live By (Chicago: University of Chicago Press, 1980). 
Schrauwen further explores the connection between red, warmth, and sexual tension. A telling example is during Roger and Louis's sexual encounter in the city scale model. The colour then changes from red to blue when Arsène is mentioned during the love-making. ${ }^{76}$ Different colours can also be attributed to characters, especially when their worlds are or seem apart from each other (Fig. 11). Changing colours can also be applied in a more traditional way, to indicate that a panel is part of another story level, such as a dream or a memory.

\section{Figure 11 near here}

By means of layering and superimposition, Risography also allows for colour mixing. Olivier Schrauwen uses this possibility for dream sequences ${ }^{77}$ or for representing the coming together of two simultaneous sequences differentiated by colour, as in the embrace of Arsène and Marieke (Fig. 11). Interestingly, the first six pages of the final chapter called 'Arsène' have one more colour: black is used for contour lines and shades and all panels are printed in mixed colours. ${ }^{78}$ The colour scheme seems to imply that Arsène has come to an equilibrium, that he has come to terms with what happened and that all strong emotions have passed. The return to the simple blue of the first pages in the closing sequence, however, indicates that whatever Arsène learned is again lost in the end. Everything returns to normal, the hybrid state is over.

Besides these meaningful colour transitions and overlaps, Arsène Schrauwen also features longer chunks of narrative that are monochromatically consistent, without specifically motivating the colour choice, coming closer to the way in which it was used in Suske en Wiske. In this sense, the use of colour in Schrauwen's book is not as systematic and narratively integrated as in David Mazzucchelli's Asterios Polyp ${ }^{79}$ which uses chromatic codes to distinguish the very different 'worldview' of the two main characters. In Arsène Schrauwen, there is a permanent back-and-forth between the unmarked monochromatic function of both colours and their integration to the story unfolding.

With the blue and red colouring, the linear drawing style and the thin, matte paper, Schrauwen takes a very simple reference to the Suske en Wiske adventure stories he grew up with (some of which were set in Africa) and researches its possibilities to the extreme. Every visual choice is meaningful.

The reference to Marc Sleen's Nero is less obvious, although Arsène has inherited traits from the main character Nero as much as from Suske and Wiske's friend Lambik, as much physically as psychologically (i.e. his naiveté). Nero's Africa was a place of wonders, where inhabitants could be intelligent people and cruel cannibals at the same time. Mostly, Sleen drew non-white races very stereotypically, ${ }^{80}$ but this may in part be attributed to respecting a visual tradition of caricatures rather than to intentional racism. As explained above, Arsène Schrauwen hardly ever shows black people, but Arsène is very uneasy about them. Just like Suske en Wiske, Nero has always mixed adventure and humour, a tradition honoured by Olivier Schrauwen in his take on the Congo. Perhaps the most tangible influence of Nero on Arsène Schrauwen is Sleen's tendency towards chaos, in story lines, unusual events, but sometimes also in the drawing. As Jan Baetens showed, there are some Nero comics from the early fifties where the grey screens do not match the black contour lines, resulting in an anarchistic use of shading techniques, foreshadowing Schrauwen's use of abstract patterns in his books, especially in Arsène Schrauwen. ${ }^{81}$

This spontaneous, anti-academic attitude towards cartooning that Schrauwen shares with Sleen is also clear in the 'negligent' finishing of his work. His decision to print and distribute the parts of Arsène Schrauwen himself betrays a mistrust of editors and publishers as well as a strong attachment to a segment of comics production that is often overlooked by critics and scholars primarily interested in graphic novels: the world of small-press and self-publishing in which Schrauwen has always felt at home. ${ }^{82}$ Many international publishers of his work predominantly operate in the small press community. This preference for editorial freedom and a do-ityourself mentality arguably explains why Schrauwen embraces the printing errors of primitive risography. In this sense, the quirkiness of the phrasing in his non-native English is equally logical. It even partially explains why Schrauwen writes most of his work in English in the first place. The world of independent and micropublishing is thoroughly international and Schrauwen can be sure that an English version will certainly attract more readers

\footnotetext{
76 Arsène Schrauwen, 91.

77 Arsène Schrauwen, 75.

$78 \quad$ This is the same colour scheme as the Suske and Wiske albums published between 1959 and 1967 (cf. supra).

79 David Mazzucchelli, Asterios Polyp (New York: Pantheon Books, 2009).

80 Idesbald Goddeeris, 'The Japanization of China. Chinese Images in Belgian Comics in the 1930s and 1940s', in Rechtsextremismus, Rassismus une Antisemitismus in Comics [Extreme right, racism and antisemitism in comics], ed. Ralf Palandt (Berlin: Archiv der Jugendkulturen Verlag KG, 2011), 121-134.

81 Jan Baetens, 'L'art brut van Marc Sleen' [Marc Sleen's art brut], Kreatief. Driemaandelijks Literair en Kunstkritisch Tijdschrift 31.5 (1997), 88-95.

82 See Meesters, 'The Reincarnation of Independent Comics'.
} 
than a version in his mother tongue Dutch, which is not the case for most Flemish cartoonists. ${ }^{83}$ His American publisher even considers the strange English an essential quality of Schrauwen's work and did not want to intervene in things other than spelling. ${ }^{84}$ The same attitude towards spontaneity and the embrace of errors can be seen in the drawings.

\section{Form and Function}

Comics, as Laurent Gerbier has convincingly suggested, are perhaps distinctively suited to deal with the travel motif and the exploration of space because it is a form that itself is all about organizing the space of the page, double page, or even the book: 'Among narrative and visual arts that attempt to represent the transformations of our relationship to space, comics occupy a privileged position - maybe because the form itself is constantly trying to redefine its own way of occupying and constructing the space of the page and of the drawing ${ }^{85}$ Drawing on this medium-specific exploration of space, Arsène Schrauwen maps out the character's voyage on the page in a self-reflexive manner, emphasizing the interplay between the story told and its telling or showing.

By constantly attracting attention to the mechanics of comics storytelling, Arsène Schrauwen declines to seek to sustain a transparent simulation of a 'possible world', and downplays narrative immersion: what matters is not only the story, but how it is told and shown. The reflexive play and the inventiveness of the graphic narration are central to the book. In this sense, Schrauwen continues the baroque metaleptic gesture, the reflexive irony which, according to Thierry Smolderen, is at the heart of the history of comics and the endurance of the form: just as his predecessors sought to add 'a double layer of irony every time their language $r$ [an] the risk of stiffening or becoming established', ${ }^{86}$ Schrauwen adopts the graphic novel with some ironic distance.

First, he proceeds to a conspicuous 'defamiliarization' of some of the most entrenched conventions in comics.$^{87}$ This is clear in the composition of the pages or the facing pages, which often strays away from conventional layouts. ${ }^{88} \mathrm{~A}$ circular arrangement of panels can occur, but the borders can also disappear in order to suggest simultaneity, or the layout can suggest the form of the female figure upside down ${ }^{89}$ Most remarkably, Schrauwen often fills the blanks in between and around the panels with (abstract) patterns that correspond to the scene within them. Once, the panels are even arranged between the branches of a tree. ${ }^{90}$ These layout techniques force the reader to deviate from the normal left to right reading path and problematize the naturalness of our reading habits in comics.

A second way of drawing the reader's attention to the conventions of comics narration is by exaggerating them. A light bulb works as a conventional pictogram for an idea in a comic, but when it is merged it with an enormous moon, the symbol as such is comically distorted and foregrounded (Fig. 12). Curses are often suggested by unreadable characters in comics, but on one page they are so big that the reader will probably notice them anew as the strange unreadable characters that they are. ${ }^{91}$ Diegetic images can even serve as emanata, as the footprints that Arsène left on the roof of his room the previous day suddenly become exclamation marks as he wakes up from a puzzling dream. ${ }^{92}$ This example embodies the comic interplay between the story and its graphic rendering.

83 See Meesters, 'De internationalisering van de Vlaamse strip' and Gert Meesters. 'Willy Vandersteen and His Legacy. Comics Publishing in Antwerp from 1945 to the Present Day.' De Gulden Passer. Journal for Book History 92 (2014), 125-141.

$84 \quad$ Eric Reynolds, p.c., 30 January 2015.

85 'Parmi les arts narratifs et visuels qui tentent de rendre compte de ces transformations du rapport à l'espace, la bande dessinée occupe une place privilégiée - peut-être parce qu'elle ne cesse, elle-même, de redéfinir sa propre manière d'occuper et de construire l'espace de la planche, de la page et du dessin'. Laurent Gerbier, 'La conquête de l'espace (touristes, héros volants et globe-trotters)' [The conquest of space (tourists, flying heroes and globe-trotters)], Neuvième art 2.0., August 2012: http://neuviemeart.citebd.org/spip.php? article438. [accessed 1 September 2015]

86 Thierry Smolderen, Naissances de la bande dessinée de William Hogarth à Winsor McCay (Brussels: Les Impressions Nouvelles, 2009), translated into English by Bart Beaty and Nick Nguyen under the title The Origins of Comics: From William Hogarth to Winsor McCay (Jackson: University Press of Mississippi, 2014), 56

87 Victor Shklovsky, 'Art as Technique', in Literary Theory: An Anthology, eds. Julie Rivkin and Michael Ryan (Hoboken: Wiley-Blackwell, 2004), 15-21.

88 See Benoît Peeters, Case, planche, récit : lire la bande dessinée [Panel, page, narrative: reading comics] (Paris, Flammarion/Casterman, 20031998), 39-64.

89 Arsène Schrauwen, 179.

90 Arsène Schrauwen, 189.

91 Arsène Schrauwen, 105.

92 Arsène Schrauwen, 230. 


\section{Figure 12 near here}

Schrauwen further hones the fundamentally reflexive role of drawing in comics storytelling, what Philippe Marion influentially termed 'graphiation', and accentuates a distinct 'voice' strongly present in the telling of the story. ${ }^{93}$ In this way, Schrauwen repeatedly reminds the reader that the fictional storyworld is just flat, drawn artwork. As Robert Crumb would put it, 'It's only lines on paper, folks'. ${ }^{44}$ By strengthening this foregrounding of the drawing and of the lines, Schrauwen stresses the two-dimensionality of his drawings and explicitly undermines the illusion of mimetic resemblance. When Arsène first enters the hall where Desmet's scale model of a city is being built, there is clearly something wrong with the picture. In fact, the number of steps in the staircases is not the same on both sides of the picture, resulting in an Escher-like confusion. ${ }^{95}$ When the Bricolage monument is assembled in a barn, there is again something wrong with the three-dimensional impression, as objects that should become smaller because of the growing distance, actually look bigger. ${ }^{96} \mathrm{~A}$ jungle road that seems to disappear far away in the distance, in fact ends in a sharp angle nearby (Fig. 13). Every suggestion of depth in comics is an illusion, as the narrator implicitly reminds us when he says: 'The forest appeared to be devoid of depth. It was as if they were riding through a tunnel decorated with the strange and random shapes one would find on a moth-ridden rag' ${ }^{97}$

\section{Figure 13 near here}

The thematisation of representation by line drawings in Arsène Schrauwen allows for thorough exploration of the process of projection as subtle and sometimes more abstract interactions are constructed between Arsène's perception and the graphic storytelling. To achieve this, Schrauwen relies on three conspicuous stylistic techniques.

A first prominent feature is the very particular use of blank heads, hollow circles that stand in for anyone and everyone. This specific representation of the face follows a growing trend among cartoonists such as Chris Ware or Ruppert \& Mulot, who problematize and subvert the key role that facial expressions play in comics storytelling, ${ }^{98}$ by making the traits or the expression of (some) faces unreadable. ${ }^{99}$ What is interesting in Arsène, moreover, is that Schrauwen does not 'simply' use blank heads in a fixed, static manner, but that these blank circles often morph into actual faces: this is most often the case with Roger Desmet's assistant Louis, whose face is usually a bespectacled circle but occasionally takes on more specific features (Fig. 14). This technique is used to highlight the role of facial expressions in communication, the act of recognizing a face and projecting emotions and thoughts onto it: in another example, Arsène cannot 'read' Marieke's face, which is otherwise usually clearly visible and readable, and this moment marks a distance between both characters that will not be reconciled. ${ }^{100}$

93 Philippe Marion, Traces en cases: Travail graphique, figuration narrative et participation du lecteur [Traces in panels: graphic work, narrative figuration and readerly participation] (Louvain-la-Neuve: Academia, 1993). In English, see also Jan Baetens, 'Revealing Traces: A New Theory of Graphic Enunciation', in The Language of Comics: Word and Image, eds. Robin Varnum and Christina T. Gibbons (Jackson, University Press of Mississippi, 2001), 145-155 ; Jared Gardner, 'Storylines', SubStance 40.1 (2011), 53-69.

94 This is the final sentence of his one-page comic 'Drawing Cartoons Is Fun!', Robert Crumb's Despair (San Francisco, Print Mint, 1969). It was reprinted as the backcover of Peter Poplaski and Robert Crumb, The R. Crumb Handbook (London: MQ Publications, 2005).

95 Arsène Schrauwen, 32.

96 Arsène Schrauwen, 131.

97 Arsène Schrauwen, 165.

98 Baetens and Frey, The Graphic Novel, 175.

99 Interestingly, in the same month as Arsène Schrauwen, another Flemish graphic novel appeared with the exact same blank circles for the faces of some characters: Junker by Simon Spruyt (Blloan, 2014). As both books had been several years in the making, their mutual relationship and possible influence is hard to determine. The similarity between both books goes even further: they share an unreliable narrator and a historical setting (in Spruyt's case the Great War). In previous works, Spruyt has made use of self-parody, mocked the graphic novel marketing and the comics industry in general ( $S G F$, 's Hertogenbosch, Silvester, 2010). Schrauwen en Spruyt are both male cartoonists born in the late 1970s who studied comics at LUCA School of Arts in Brussels almost in the same period, so part of Schrauwen's themes might be generational. Arsène Schrauwen, 193. Some objects get a visual treatment that is comparable to these human characters with a blank circle instead of a face. This results in lack of detail and very schematic rendition of boats, 


\section{Figure 14 near here}

Secondly, there is the playful redundancy between word and image, consciously breaking one of the most pervasive implicit rules in contemporary comics storytelling, namely that there should not be too much overlap between the two. In Arsène, a metaphor or another figure of speech (comparison, metonymy) used in the text is literally realized in the image, to great humorous effect. For instance, when he gets out of the boat, the heat 'hit him like a piano dropped from a five-story building' and indeed, the image shows just that. In the same way, Schrauwen repeatedly visualizes entrenched textual metaphors based on animals. The erect donkey, for instance, finds its origin in the expression 'bander comme un âne' [get a hard-on like a donkey] in French and the similar 'een erectie als een paard' [an erection like a horse] in Dutch. Similarly, the ostrich that accompanies Arsène embodies cowardice, based on expressions like 'de kop in het zand steken' [to stick one's head in the sand]. Another expression that may escape readers who do not read Dutch occurs in the images where Arsène is portrayed as a decapitated chicken; indeed, the Dutch expression 'een kip zonder kop' [a headless chicken] means 'somebody who has lost his/her mind'. ${ }^{101}$

Through this technique, Schrauwen gradually constructs a set of visual metaphors that are re-used throughout the book and which become metaphorical for certain emotions in rather stable ways: the donkey, as already mentioned, systematically stands in for lust and/or for lack of intelligence. The references in other forms of visual metaphors appear less obvious. When Arsène receives a wrapped uncooked chicken from his 'boy', the scene in which Arsène is represented as a headless chicken for the first time, he is at first repelled, since he takes the animal to be a human nutsack because of its texture. In the following panels, the chicken progressively turns into a human body. ${ }^{102}$ The disturbing evolution of the image somehow crystallizes Arsène's estrangement from his surroundings, his fear, and his ambiguous relationship with the 'boy' - all mingled with popular stereotypical images of cannibalism. Based on the literal repetition between image and text, this set of verbal-visual metaphors constitutes a filter expressing Arsène's experience and feelings as he travels into the unknown, blending both the subjective and objective planes together.

Finally, the third technique is less particular to Arsène and harder to systematize. Arsène Schrauwen stages a mobile and dynamic parallel between graphiation and perception, exploring how abstract lines can be assembled into neat clean narratives, if only by means of projection.

Announced on the back cover, projection indeed constitutes one of the questions the book professedly deals with: the very act of projection is repeatedly staged in the book as a mode of interpretation that draws a particular meaning out of different, often unrelated elements into a kind of bricolage. Arsène indulges in the activity, as when 'his mind translated the fuzzy dream imagery into this neat narrative', ${ }^{103}$ or when he projects himself into the pulp story he is reading. ${ }^{104}$ But this act of projection is most conspicuously highlighted by the game at the end of the pulp omnibus: a puzzle, 'a jungle of lines' in which the reader has to find a lion. Tellingly, the caption reads '[o]ne could project everything onto anything'. And indeed, Arsène, instead of identifying the animal in the 'jungle of lines' of his book, simply gazes at the jungle in front of him and projects onto the shrubbery various figures: a lion first, and subsequently, a naked Marieke, of course. Following this logic, any more or less random arrangement of lines can be turned into a recognizable pattern to which meaning can be attributed. This process also happens later in the book, for instance when he sees figures emerge from the smoke of his cigarettes. ${ }^{105}$ Things do not, however, always pile up, and a telling image closes off this episode by having Arsène sitting in the night, watching a spectacle of fireflies - clearly evocative of a film projection - but without 'reading' a narrative from it: 'No particular pattern emerged. He just gaped at the spectacle, at the small comets flaring up and then dying' (Fig. 15).

\section{Figure 15 near here}

Arsène's repeated projection onto abstract lines and motifs is itself mirrored in the recurring abstract motifs throughout the book, whether in the panels themselves, in backgrounds or even in the paratext. ${ }^{106}$ Schrauwen uses abstract motifs taken from the story and blows them up as the décor against which the panels and the drawings are set: usually these backgrounds do not play any direct role in the unfolding narrative, they

cars, hospitals or machines.

101 Arsène Schrauwen, 49, 96. Visualizing entrenched metaphors has been a key topic in cognitive studies of comics, see for instance Elisabeth El Refaie, 'Looking on the Dark and Bright Side. Creative Metaphors of Depression in Two Graphic Memoirs', Auto/Biography Studies 29.1 (2014), 149-174.

Arsène Schrauwen, 48-49.

Arsène Schrauwen, 59.

Arsène Schrauwen, 66.

Arsène Schrauwen, 213.

Arsène Schrauwen, 122-123. 
mostly have an aesthetic and perhaps descriptive function, but they also obviously highlight how abstract stains, blots, motifs can take on a certain meaning in certain contexts. This is for instance clear when such backgrounds come at strategic places such as the opening of new chapters or interrupting two grid pages. They can seem (at first glance) to function as strictly decorative, non-narrative elements, but they can also sometimes be linked to the preceding panel, and therefore maintain a relationship with the diegetic world: as for instance, a page which builds both on the bubbling wounds of the scout and on an abstract form of orgasm - somewhat in the vein of Lewis Trondheim's La nouvelle pornographie [New pornography] -, ${ }^{107}$ or in another, which urges us to find motifs of the book in smoke shapes, ${ }^{108}$ or the very last page, which is 'simply' blue, and which both refers to Arsène entering into the dark night and to generational transmission, the permanence of the shared physiognomic traits between Arsène and 'Olivier' announced in the first page. ${ }^{109}$

In the context of a journey to the colony, this relationship between perception and graphic lines foregrounded in Arsène is further linked to the idea of mapping reality, of lines that can account for it. This is evident from the start: when Arsène sets foot in the colony, the way to his cousin's house is represented as a plan that he is following like an automat. ${ }^{110}$ In another particularly interesting sequence, Arsène is supposed to guide the convoy across the jungle, by following the map: while Marieke explains the plan to him, however, he prefers to admire how her hair intertwines with the patterns of her dress; as a result, he turns out to be unable to read the plan on the rocky road, and the drawings intertwine his intuitive navigation through the jungle with the pattern of the dress, as if that were the actual map he was following. ${ }^{11}$

\section{Conclusion}

On the whole, in Schrauwen's book, this question of 'graphiation' and perception suggests that somewhat random elements may provide new interpretations. This is in turn mirrored in Roger Desmet's grand architectural project and his aesthetic of bricolage. Desmet holds that 'all human artifacts could be broken down into a set of universal forms, these could be interchanged and recombined across cultures in exciting new configurations'. ${ }^{12}$ Without the allusion to universality, this idea finds echoes in Jacques Derrida's famous essay 'Signature, Event, Context', in which he posited that any sign or mark holds the 'possibility of disengagement', which can be realized by a 'force of rupture' and 'citational graft' separating the sign from its context of production. ${ }^{113}$ Like Desmet, Olivier Schrauwen builds his art with objets trouvés from a wide variety of sources and deploys them for something new. ${ }^{114}$ This is perhaps what Arsène Schrauwen is all about: in one of the last pages, Arsène climbs up the mountain, and considers 'the phenomenon of echoes' and how an 'extremely sensible receiver would still be able to perceive it 50 years from now': the 'message' that Arsène sends into the future is his own name. ${ }^{115}$ This moment can be read as a meta-reflexive signpost about the work itself: quite evidently, Olivier Schrauwen, writing an imaginative biography of his grandfather Arsène, draws on an echo from the past that he reinterprets to make something completely new. Quite possibly, ' 50 years from now' can be interpreted both as referring to diegetic time and as testifying to Schrauwen's aim of creating a comic that would stand the test of time, a book that will resonate for years after its publication. With Schrauwen, irony is pervasive but does not stand in the way of ambition.

The reappropriation of disparate elements is a technique that underwrites the aesthetic project of Arsène Schrauwen in its entirety. Schrauwen not only draws on his family history to create something very different from what one might have expected; he also recuperates tropes, discourses, and stereotypes from the Belgian colonial memory in original, off-kilter fashion; he displays an acute awareness of the history of comics and its traditions; and finally, he self-reflexively addresses the very process of 'bricolage' through a myriad of$$
\begin{aligned}
& \text { 24. And, we know how much this question of citation is, in comics, a question of lines, see Bart Beaty, 'A } \\
& \text { Clear Line to Marcinelle: The Importance of Line in Émile Bravo's Spirou à Bruxelles', European Comic }
\end{aligned}
$$
Art 4.2 (2011), 199-211.

114 In this way, the parallels that Schrauwen draws between architecture and comics differs radically from other well-known examples as those of Winsor McCay and Chris Ware: he does not specifically underline the similarities between the grid, the page layout and the cross-section facades of a building. See Catherine Labio, 'The Architecture of Comics', Critical Inquiry 41.2 (2015), 312-343.

Arsène Schrauwen, 182. Lewis Trondheim, La nouvelle pornographie. (Paris, L'Association, 2006). Arsène Schrauwen, 74.

Arsène Schrauwen, 257. See Steven Surdiacourt, 'Blacks and Blanks: On “Empty” Panels', Comics Forum, 25 May 2012: http:/comicsforum.org/2012/05/25/image-narrative-4-blacks-and-blanks-on-empty-panelsby-steven-surdiacourt/. [accessed 1 September 2015]

Arsène Schrauwen, 18-19.

Arsène Schrauwen, 185-188.

Arsène Schrauwen, 36.

Arsène Schrauwen, 246-247. 
techniques that make Arsène Schrauwen stand out as an original, innovative, and compelling contribution to the exploration of its medium. The bricolage link between Olivier Schrauwen and Roger Desmet might also explain why the story does not end with the seeming equilibrium in three colours. ${ }^{116}$ Apart from the colour scheme,

several story elements suggest that this period offers much desired peace and quiet for the main characters. Black people have now become recognizable humans who speak French, instead of unknown, fear-inspiring creatures that supposedly need to be disciplined. Freedom Town - or Lippensville - has grown according to the laws of real-life economy and the emotional ties between Marieke, Roger and Arsène have become stable and socially acceptable. Instead of settling for this equilibrium, the story bites its own tail, for Arsène returns to his monochrome blue world in an unchanged Belgium. Apparently, both Roger Desmet, who tried to reinvent architecture from scratch, and Olivier Schrauwen himself prefer the imaginary world of their creations to the dull reality of doing the dishes.

116 Arsène Schrauwen, 250-253. 